\title{
The Inquiry Learning Model Uses Small Steps Technique Google Drive on Chemistry Learning Student Class X TAV at SMK PIRI 1 Yogyakarta
}

\author{
Hadiyanto Sahputra ${ }^{a,{ }^{*}}$ \\ a Sekolah Menengah Kejuruan 1 PIRI, Yogyakarta \\ *Corresponding author: hadiyantosahputra2015@gmail.com
}

\begin{abstract}
The aim of this study is to know the learning method of Inquiry Learning Small Steps in the chemistry subject through online learning with Google drive media. This study includes an assessment of learning activities and student achievement in chemistry lesson. Object of this study were students of $X$ Class of Technical Audi-Video program (X TAV) in the academic year 2016/2017 of SMK PIRI 1 Yogyakarta. The number of objects examined were 15 students consisting of 15 male and 1 female students. Stages of inquiry learning is providing problems, formulating problems, making hypotheses, collecting data, examining hypotheses and making conclusions. Data collection using observation sheets, tests and questionnaires. The data obtained were analyzed descriptively. Based on the research results obtained that: (1) The use of google media drive can increase student learning activity in the material of atom structure in chemistry lesson. This can be seen from the value of student activity with score 4 (good), student's response value is $85 \%$ (Very Positive) and the value of student learning result Pre cycle is $41 \%$, Cycle $1: 54 \%$ and Cycle $2: 85 \%$.
\end{abstract}

Keywords: Learning inquiry, Google drive media, Media learner

\section{INTRODUCTION}

In the chemistry learning, understanding of core concepts is very important. Understanding of core concepts will allow the students to place these concepts in long term memory system and can use them to think at higher levels of thinking such as problem solving and creative thinking [1]. Understanding the core concepts will facilitate them in achieving the minimum completeness criteria (KKM) established by the school management [2].

In fact, the condition in class X TAV SMK Piri is still far from ideal condition. Student's understanding of core concepts in the chemistry subjects in everyday life is still low (average grade 65). In addition, the number of students who achieve and exceed the KKM is less than $60 \%$. KKM of chemistry subjects in the academic Year of 2016/2017 is 75 . Some causes of low understanding of students in the atomic structure material are: (1) the material of the atomic structure contains many chemical concepts (1) the material of the Atomic Structure contains many chemical concepts with terms that are hard to remember and understand; (2) the learning strategy used is still not sufficient to facilitate the acquisition of understanding for students.

In general, the problems encountered in the learning process of chemistry is not much different from other adaptive learning. However, the peculiarities of chemistry that learn about the natural phenomenon that cannot be seen made delivery of the message of chemistry is not easy. Consequently, it is deemed necessary for the application of an inquiry model of engineering techniques small steps material Atomic Structure in class X TAV at SMK PIRI 1 Yogyakarta. This is important as a joint effort in improving the quality of Chemistry learning which leads to improvement of students' learning achievement in Chemistry subjects.

The benefits of this research are to improve the quality of chemistry learning process and chemistry learning result on Atomic Structure material, to improve the skill/psychomotor, to improve the creativity of teachers, to improve teacher's skill in preparing the concept of learning, and to improve the insight and profession of teachers in the learning process [3]. This method also provide a broader picture that in the real world of education there are problems related to teaching and learning process and know more application of inquiry Learning that can be used to solve problems in the classroom. 


\section{METHOD}

The design of activities in the course of Laboratory Management includes:

This research is a type of inquiry research. Inquiry learning is a strategy of exploring students' knowledge [4]. There are four important stages in the implementation of inquiry learning that is making hypotheses, collecting data, interpreting evidence and drawing conclusions [5].

The small steps technique is a technique of learning by applying a practical exercise sheet from the easiest to the most difficult point [6]. By giving the question of the easiest is expected students will become confident and will try to dig deeper knowledge by doing the higher level of the problem. Selflearning ability is the ability to set goals and solve difficult problems independently. Google Drive is a file sharing service owned by Google, by creating a gmail account to access google drive features. Google Drive has several functions, one of which is a place to back up data, and share files that have been uploaded before. Making a test or exam online with google drives fairly simple and very easy.

In the learning activities, motivation can be said as the overall driving force within the students that leads to learning activities and that gives direction in the learning activities, so that the desired goal of learning subjects can be achieved [6].

Learning motivation is a non-intellectual psychological factor. Its distinctive role is in terms of growing passion, feeling happy and eager to learn [7].

This learning motivation is very important and an absolute requirement for learning. In school often students who are lazy to learn, like to ditch and so forth. In this case the teacher is said to not succeed in providing the right motivation to encourage students to work with all knowledge and ability. In this connection a bad score on a particular subject does not mean that the child does not understand the subject. Thus in the learning process, motivation is necessary because someone who has no motivation in learning, will not be possible to do learning activities [7].

The variables that will be sought through this research are: Inquiry Model of Small Steps Technique with cognitive approach and Chemical Learning Achievement. The research was conducted at SMK PIRI 1 Yogyakarta in class X TAV of academic year 2016/2017 on 15 July-15 September 2016. Indicator of success, If there is achievement of improvement of absorbing power equal to $75 \%$ from absorption of students. (Corresponding KKM for Chemistry Class X is 75).

The stages of using Google Drive module:

1. Google account has been prepared then open the following address link: www.drive.google.com

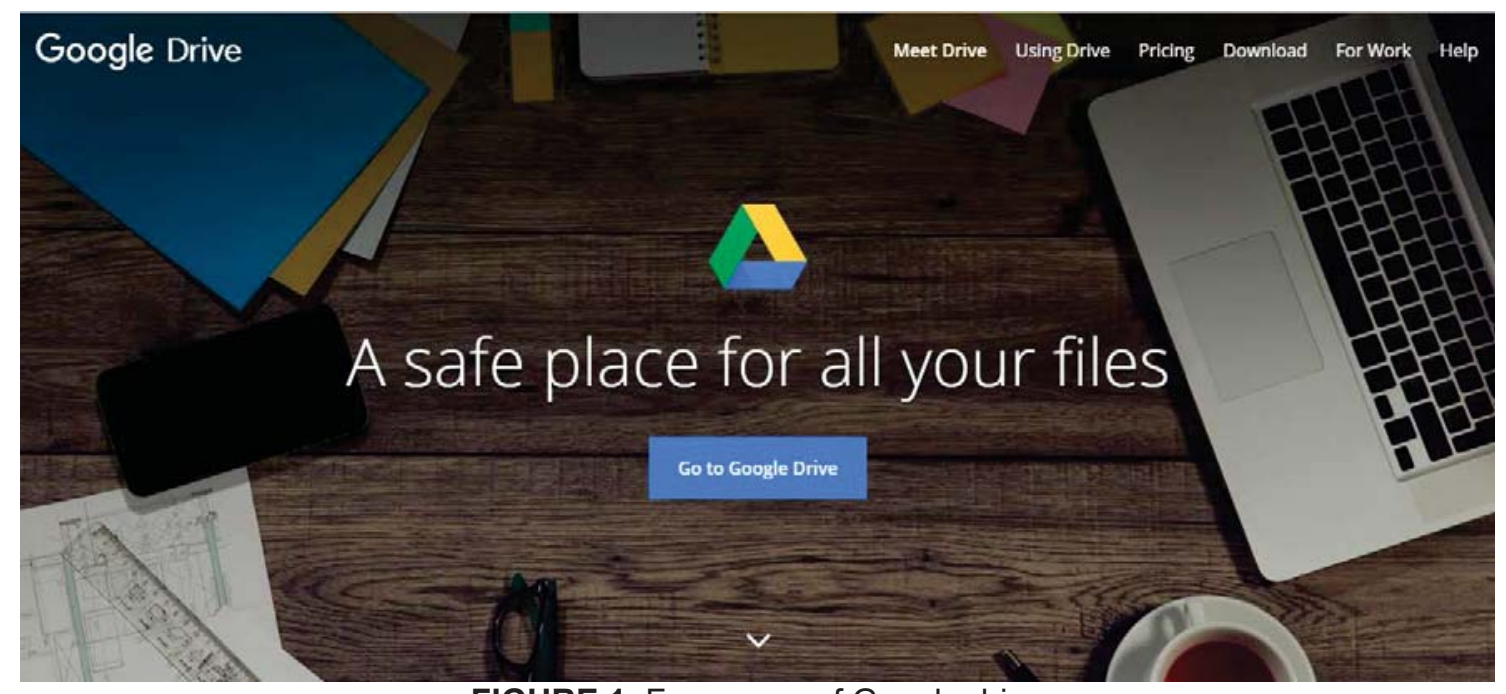

FIGURE 1. Face page of Google drive 
2. Enter the account Gmail

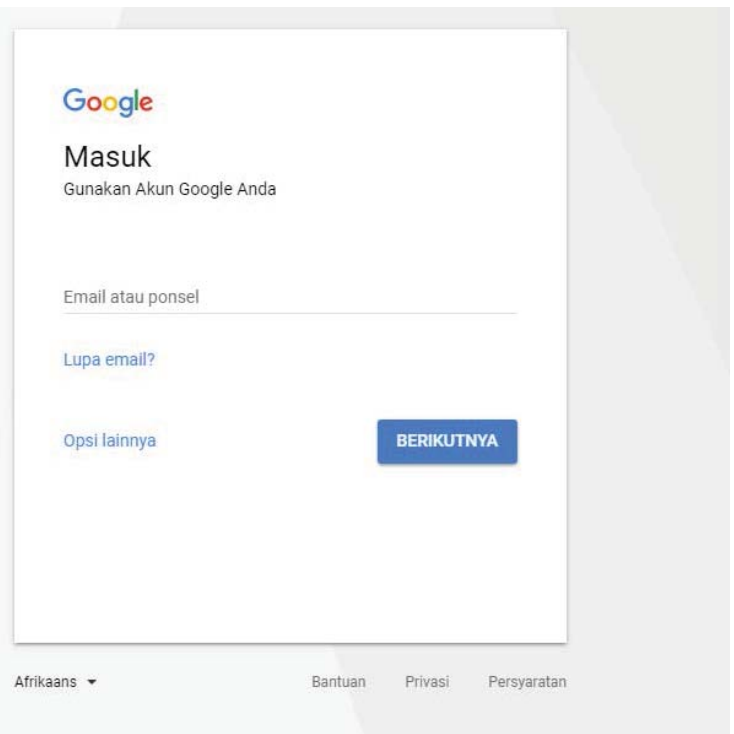

FIGURE 2. Face page of "sign in" in Gmail

3. Online Working Matter

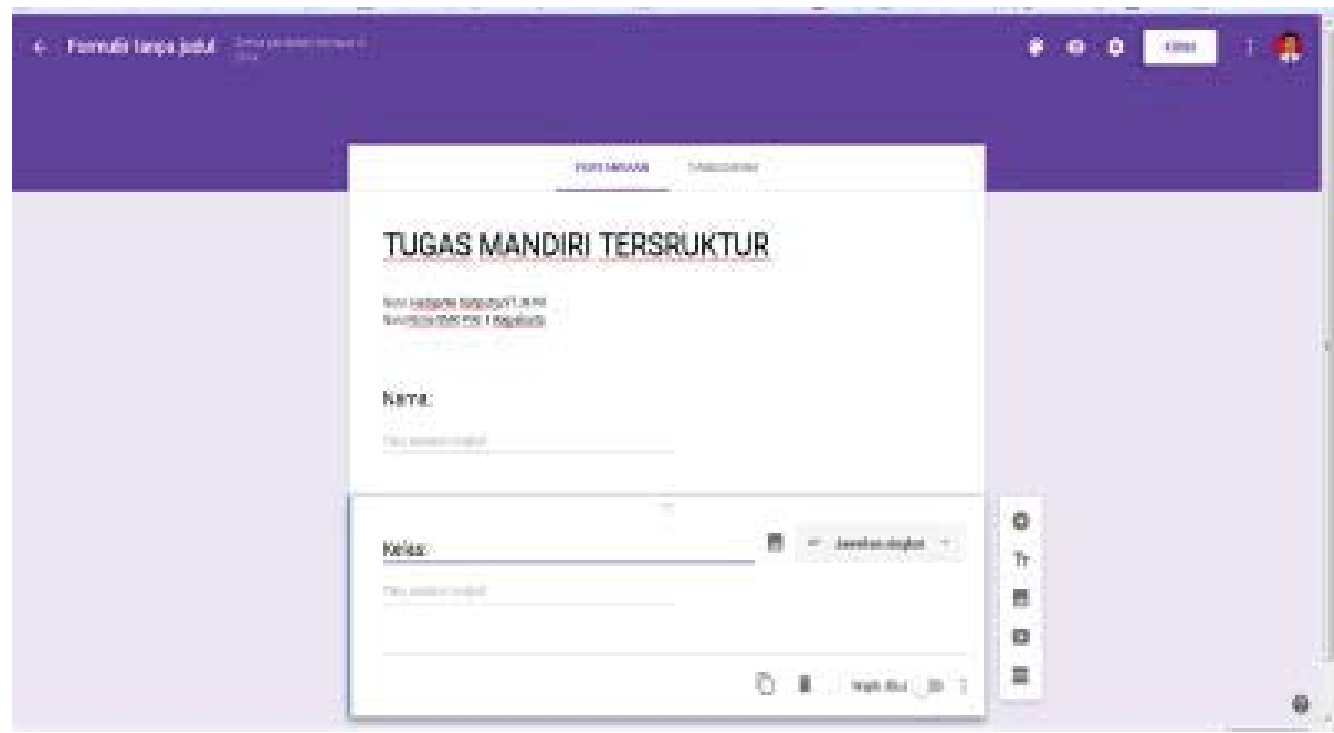

FIGURE 3. Face page of Google drive form

Qualitative data collection techniques have used inquiring the data collection method that is technique through questions by researchers. Data collection techniques can include interviews, questionnaires, attitude scales, or tests [8]. 
TABLE 1. Success Level Aspects of Learning

\begin{tabular}{ll}
\hline Percentage & Level of success \\
\hline $86 \%-100 \%$ & Very good \\
$76 \%-<85 \%$ & Good \\
$51 \%-<75 \%$ & Good Enough \\
$0-<50 \%$ & Not good \\
\hline
\end{tabular}

The steps of inquiry learning method are:

1. Orientation. This stage is the stage where the first student to be introduced to the problem.

2. Formulating the problems. The formulation of this issue encompasses the challenge of what to look for in response to the issues raised.

3. Teachers ask for temporary or temporary (hypothetical) answers from students regarding the issues discussed together.

4. Data collection. After students have a temporary suspicion of the cause of the problem, then the next step students are asked to find supporting data as the process of proofing the hypothesis

5. Test the hypothesis. From the data that has been collected, then used to test the hypothesis so that it will be proven whether the hypothesis is true or false.

6. Conclusion. The conclusion is obtained after all the evidentiary steps have been implemented. The conclusions that have been made can then be communicated to the other students through the presentation [9].

\section{RESULTS AND DISCUSSION}

In the implementation, the Research has been adjusted to the stages and procedures that have been planned previously. From the implementation of this research, obtained the data needed to be evaluated. The data obtained is a result of observation of the students during the implementation of the study. Data taken in the form of data test results increased ability to analyze the atom structure of inquiry learning in class X TAV SMK PIRI 1 Yogyakarta

Observations conducted by researchers with chemistry subject teachers. From this observation can be seen the problems of students in following the chemistry lesson of atomic structure materials. The observations that have been done are: (1) the learning applied by the teacher is conventional, (2) students only rely on the record of the teacher and guided by LKS, (3) students lack motivation, children who have high motivation in doing task (4) students are afraid to ask teachers about things that are less clear, (5) students are less understanding of the concept of Atomic structural materials.

In the initial test phase the researcher gives the concept of atomic structure test. The result of pretest ability of students in analyzing the understanding of the material of atom structure can be seen in the Table 2. below.

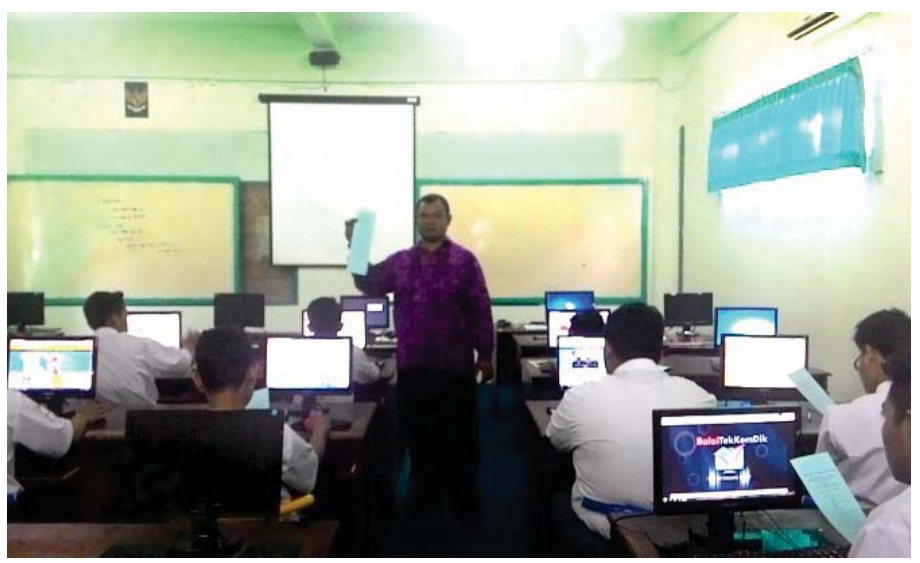

FIGURE 4. Socialization and explanation how to use google drive 


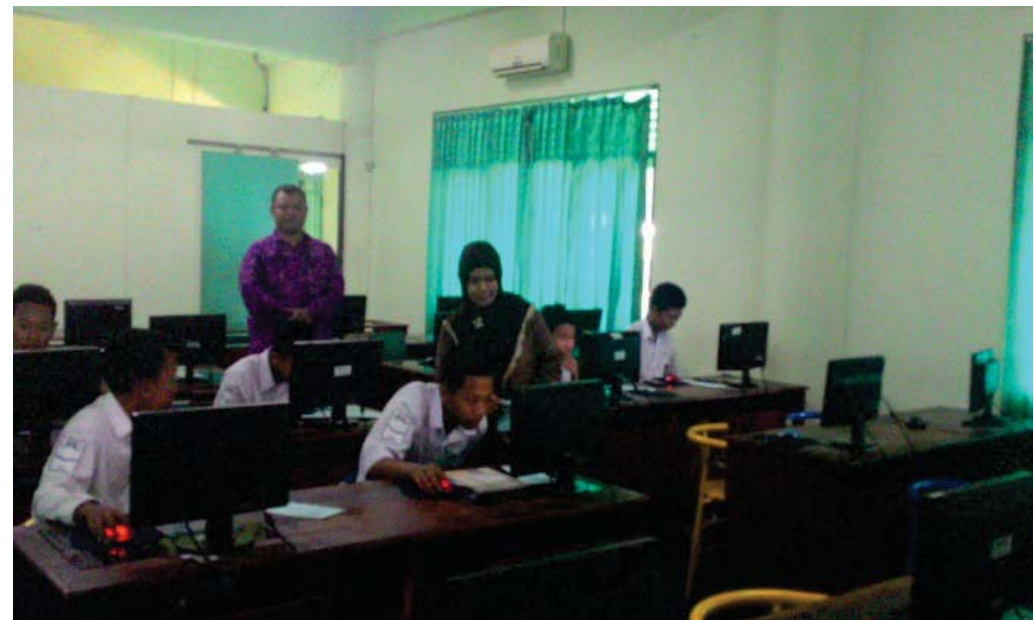

FIGURE 5. Analysis of the chemist collaborator

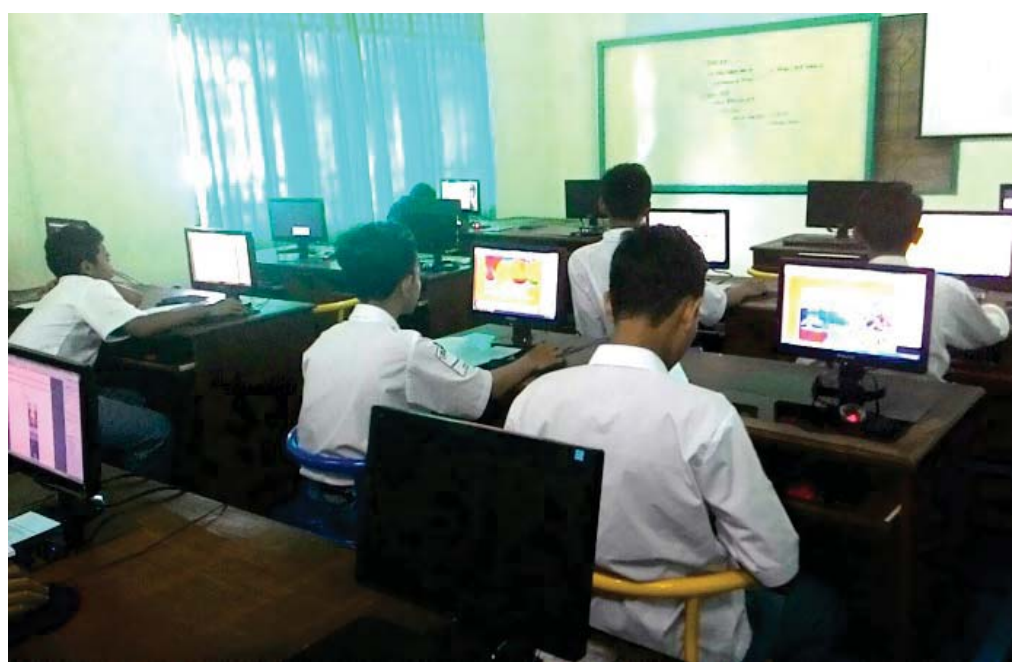

FIGURE 6. Learning uses the small steps of google drive media

The results of this study are based on the results of observation and evaluation of the students' ability test in understanding the materials of atomic structure and Atomic Component through inquiry learning. This can be seen from the results obtained students in each cycle start the initial test, cycle I and cycle II.

The results of this study were found based on the results of observation and evaluation of students' ability test in understanding the materials of Atomic Structure and Atom structure through inquiry learning. This can be seen from the results obtained students in each cycle start the initial test, cycle I and cycle II

(1) The ability to understand the material of the atomic structure in the initial test of the learner achieves an average value of $40 \%$ of the results obtained indicating that the ability to analyze the intrinsic elements of the atomic matter material through inquiry learning in the initial test can be categorized as less.

(2) In cycle I students reach an average value of $60 \%$ is categorized enough. From the results obtained it is known that students have increased. In the learning process took place with good but there are still problems that arise in the first cycle of students are still hesitant to ask questions to researchers who although researchers have given the opportunity to students to ask. This happens because the students are not careful and precise in analyzing the intrinsic element of understanding the matter of atomic structure through inquiry learning, so the researcher need to continue the learning to cycle II.

(3) In cycle II students reach the average value of $90 \%$ categorized Good. From the results obtained is known students have increased value in understanding the material of the atom through the inquiry learning. Improvement in the value of cycle II is caused because students no doubt ask the researchers about things that are not understood., Based on the above, the researcher decided to continue the 
research in cycle II. As for result of improvement of study analyze understanding material atom structure and atom constituent.

Result of learning student activities

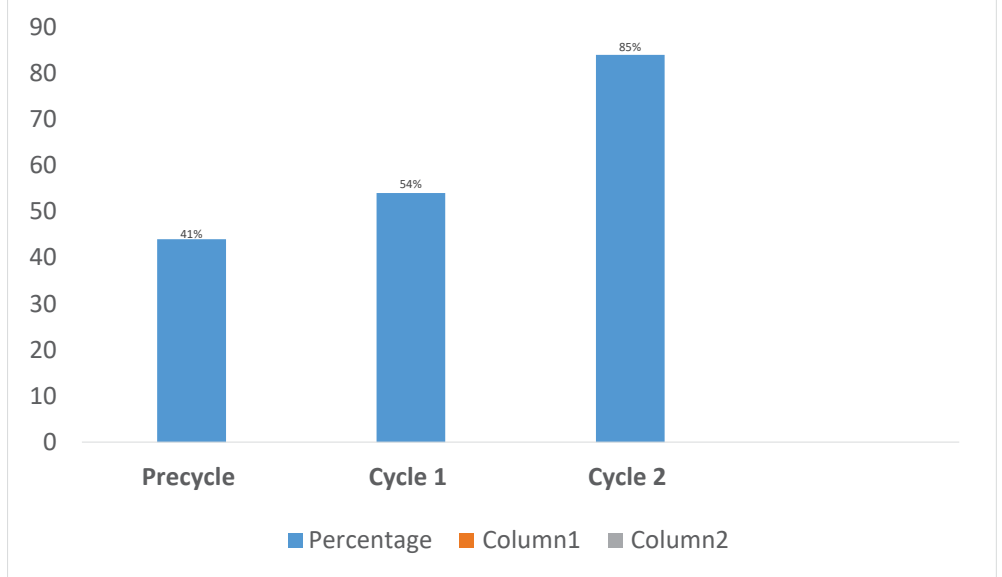

FIGURE 7. The result of Leaning analysist

Figure 4. above shows that students' learning outcomes in analyzing atomic structure materials on inquiry learning are increasing, from the initial test $41 \%$, cycle 1 is $54 \%$ and Cycle 2 is $85 \%$.

TABLE 2. Average of Student response results

\begin{tabular}{cccc}
\hline No & Value Aspect & Average & Category \\
\hline 1 & Motivation & 3.32 & Good \\
2 & Attractiveness & 3.80 & Very Good \\
3 & Convenience & 3.90 & Very Good \\
4 & Benefit & 3.25 & Good \\
\hline
\end{tabular}

Table 2. shows that the four aspects above can be concluded that based on the aspect of motivation to get the average score of responses at 3.32 is good category, on the aspect of attractiveness to get the average score of 3.80 response is in the category very good, the aspects of ease of getting flat the response score at 3.90 is very good category and on the aspect of expediency get the average score of responses at 3.25 that is in good category, and mean of all four aspect get average score at 3.57 that is on very good category. So it can be concluded that learning technique small steps google media very well used to improve student's motivation and achievement on chemistry subjects.

The results of the implementation of the small Google drive technique learning steps are:

1. Create and socialize guidebook of character/character development for students on chemistry subjects. This seems simple but the impact is extraordinary in the learning process.

2. The target book Student achievement is made and used all students of class X SMK PIRI 1 Yogyakarta. This book records many students' activities in understanding chemistry learning.

3. The implementations of small steps learning techniques google drive media gradually for learning chemistry online.

\section{CONCLUSION}

The conclusions of this study are as follows:

1. Inquiry Learning Model Techniques of small steps google drive media can motivate students to follow very interesting and happy to follow the materials Atomic Structure Class X TAV SMK PIRI 1 Yogyakarta in general interest of students in learning chemistry. Student absorbance obtained Precycle $40 \%$, Cycle 1 of $60 \%$ and Cycle II of $90 \%$ (Good category). 
2. Inquiry Learning Model Techniques small steps google drive media can motivate students to follow very interesting and happy to follow the materials Atomic Structure Class X TAV SMK PIRI 1 Yogyakarta on. Changes in student behavior in following the lessons are very enthusiastic following this inquiry learning model.

\section{ACKNOWLEDGMENTS}

Authors thank to all those who have helped and honored the highest to: Journal Team of Chemistry Education Program of Islamic University of Indonesia. Principal SMK PIRI 1 Yogyakarta. which has helped the smoothness of this research, students of class X TAV has conducted this research. Families who have supported the conduct of this study and those who cannot be mentioned individually who have provided assistance during the writing of this study.

\section{REFERENCES}

1. Dimyati and Mudjiono, Belajar dan Pembelajaran (Depdikbud, Jakarta, 2004).

2. M. Abdurahman, Pendidikan Bagi Anak Berkesulitan Belajar, (Rineka Cipta, Jakarta, 2003).

3. A. M. Sardiman, Interaksi dan Motivasi Dalam Belajar Mengajar, (Raja Grafindo Persada, Jakarta 2000).

4. D. Llewellyn, Inquire Within: Implementing Inquiry-Based Science Standards (Corwin Press Inc, California, 2002).

5. J. A. Banks, Teaching Strategis for The Social Inquiry (Longman, New York and London, 1990).

6. A. S. Sardiman, Media Pendidikan (Rajawali Pers, Jakarta, 2009).

7. S. B. Djamarah, Prestasi Belajar dan Kompetensi Guru (Usaha Nasional, Surabaya, 2004).

8. S. Arikunto, Dasar-Dasar Evaluasi Pendidikan (Bumi Aksara, Jakarta, 2002).

9. Daryanto, Penelitian Tindakan Kelas dan Penelitian Tindakan Sekolah (Gava Media,Yogyakarta, 2011). 